\title{
Composition of Lipopolysaccharide from Pseudomonas syringae pv. morsprunorum and its Digestion by Bacteriophage A7
}

\author{
By A. R. W. SMITH, ${ }^{*}$ SUSANNE E. ZAMZE ${ }^{1 \dagger}$ AND R. C. HIGNETT ${ }^{2}$ \\ ${ }^{1}$ School of Biological Sciences and Environmental Health, Thames Polytechnic, \\ Wellington Street, London SE18 6PF, UK \\ ${ }^{2}$ East Malling Research Station, East Malling, Maidstone ME19 6BJ, Kent, UK
}

(Received 20 August 1984)

Purified LPS from a virulent cherry isolate of Pseudomonas syringae pv. morsprunorum was a
mixture of smooth and rough molecular species. Mild acid hydrolysis yielded a precipitate of
lipid A and a carbohydrate fraction which, by gel permeation chromatography, yielded three
peaks of material. The first (high molecular weight) peak was composed almost entirely of a
rhamnan, the sidechain polysaccharide. The second peak contained core oligosaccharide and
comprised rhamnose, glucose, heptose, 2-keto-3-deoxyoctonate (KDO), phosphate, glucos-
amine, galactosamine and alanine. The third (low molecular weight) peak contained KDO,
phosphate and ethanolamine. Lipid A contained glucosamine, phosphate and the fatty acids
12:0, 3-OH 10:0, 2-OH 12:0 (all ester-linked to glucosamine), and 3-OH 12:0, which was
amide-linked. The typing phage A7, which uses LPS as its binding site, was found to possess a
rhamnanase which split the sidechains from smooth LPS, releasing them as oligosaccharide.

\section{INTRODUCTION}

Pseudomonas syringae pv. morsprunorum causes bacterial canker of cherry (Prunus avium) and plum ( $P$. domesticum) trees in England (Garrett et al., 1966). Isolates from these two sources show a high degree of specificity for their homologous hosts. Crosse \& Garrett $(1963,1970)$ established that cherry isolates belonging to race 1 could be distinguished from plum isolates by their susceptibility to the typing phage A7. Freigoun \& Crosse (1975) found however that such differentiation was not applicable to cherry isolates of race 2.

Quirk et al. (1976) showed that LPS of the race 1 cherry isolate C28 was the receptor of phage A7 by demonstrating inactivation of the phage in the presence of low concentrations of purified LPS. A partial analysis of the material revealed lipid, phosphorus, rhamnose, glucose, ninhydrin-reactive material and 2-keto-3-deoxyoctonate (KDO) but not heptose. In the present paper we describe more fully the structure of LPS from isolate C28, and present evidence to show that phage A7 possesses a rhamnanase (EC 3.2.1.-) that hydrolyses the sidechains of the LPS, releasing them as oligosaccharide. A preliminary report of this work was given earlier (Smith \& Hignett, 1981).

\section{METHODS}

Organisms. These were provided by Dr C. M. E. Garrett (East Malling Research Station). Pseudomonas syringae pv. morsprunorum strain $\mathrm{C} 28$ was maintained freeze-dried and by monthly serial subculture on nutrient glycerol agar (NGA; Hignett, \& Quirk, 1979).

Phage A7 was routinely propagated on cells of strain C28 growing in the diffusible fraction of peptone/yeast extract/glycerol broth (PYG; Crosse \& Garrett, 1963). The broth $(250 \mathrm{ml})$ in a 1-litre Erlenmeyer flask was

\footnotetext{
† Present address: Department of Paediatrics, John Radcliffe Hospital, Headington, Oxford OX3 9DU, UK.

Abbreviations: KDO, 2-keto-3-deoxyoctonic acid; S-LPS, R-LPS, smooth and rough LPS; PI $_{50}$, concentration of a receptor required to inactivate $50 \%$ of a population of phage particles.
} 
inoculated with an overnight culture of $\mathrm{C} 28$ grown on NGA, and incubated with stirring at $20^{\circ} \mathrm{C}$. At midexponential phase $\left(10^{9}\right.$ organisms $\left.\mathrm{ml}^{-1}\right)$ phage was added at a m.o.i. of $1 \cdot 0-2 \cdot 0$. Lysis was usually complete within $6 \mathrm{~h}$ of further incubation, whereupon the lysate was shaken with chloroform, decanted and centrifuged at $10000 \mathrm{~g}$ for $10 \mathrm{~min}$ to remove bacterial debris. The phage suspension, containing typically $10^{11}-10^{12}$ p.f.u. ml $\mathrm{m}^{-1}$, was stored at $4{ }^{\circ} \mathrm{C}$ over chloroform.

Phage adsorption and phage sensitivity tests were done using the procedures described by Crosse \& Garrett (1963), Garrett et al. (1974) and Quirk et al. (1976).

Chemicals, enzymes and authentic standards. Rough LPS from Escherichia coli ATCC 12408 (Knox et al., 1967) was a gift from Dr Elizabeth Work. Rough LPS from Salmonella minnesota MR595, a Re-mutant, (Lüderitz et al., 1966) was provided by Dr M. Nurminen (National Public Health Institute, Helsinki). Pronase (B Grade), was purchased from the Calbiochem-Behring Corp. Ribonuclease I (four times recrystallized; from bovine pancreas) and protein standards calibration mixture for PAGE (mol. wt range 12300-78000) were obtained from BDH. Ammonium 2-keto-3-deoxyoctonate (KDO), D-mannoheptulose, methyl nonadecanoate and methyl dodecanoate were supplied by Sigma. Authentic bacterial fatty acid methyl ester mixture was purchased from Supelco S A, Crans, Switzerland; 2- and 3-hydroxydodecanoic acids were gifts from Dr Pauline Meadow, University College, London; 3-hydroxydecanoic acid was a gift from Dr S. G. Wilkinson, University of Hull.

Batch culture of bacteria and extraction of LPS. The mineral salts medium, pH 7.0, of Erikson (1945) was modified to contain $\left(\mathrm{i}^{-1}\right): \mathrm{NaNH}_{4} \mathrm{HPO}_{4} .4 \mathrm{H}_{2} \mathrm{O}, 4.3 \mathrm{~g} ; \mathrm{KH}_{2} \mathrm{PO}_{4}, 1.7 \mathrm{~g} ; \mathrm{MgSO}_{4} .7 \mathrm{H}_{2} \mathrm{O}, 0.1 \mathrm{~g}$; trace elements solution (Bauchop \& Elsden, 1960), $1 \mathrm{ml}$. Glucose $(5 \mathrm{~g})$ and polypropylene glycol $2000(5 \mu \mathrm{l})$ were combined with the salts base after being autoclaved separately. Medium (1 litre) was inoculated with the cells from a $24 \mathrm{~h}$ old NGA slope of strain $\mathrm{C} 28$ and incubated at $18^{\circ} \mathrm{C}$ for $40 \mathrm{~h}$ with stirring. Cells were harvested, washed twice with distilled water and dried by acetone treatment (Quirk et al., 1976) to yield $1.5-2.0 \mathrm{~g}$ dried cells $1^{-1}$. Purity of cultures was routinely checked using the Gram stain and by plating on nutrient sucrose agar (NSA) to detect levan production (Crosse, 1959). Pathogenicity was confirmed by demonstration of the hypersensitive response (Klement, 1963) in leaves of growing tobacco plants (Nicotiana tabacum cv. White Burley).

LPS was extracted from the dried cells with hot aqueous phenol (Westphal \& Jann, 1965) and purified by repeated centrifugation at $100000 \mathrm{~g}$ for $2.5 \mathrm{~h}$ after successive treatment with ribonuclease $\left(0.1 \mathrm{mg} \mathrm{ml}^{-1}\right)$ for $16 \mathrm{~h}$ and $4^{\circ} \mathrm{C}$, and pronase $\left(0 \cdot 125 \mathrm{mg} \mathrm{ml}^{-1}\right)$ for $2 \mathrm{~h}$ at $37^{\circ} \mathrm{C}$ and $\mathrm{pH} 7 \cdot 4$. Block electrophoresis (Quirk et al., 1976) was used to remove residual nucleic acid and lipid was removed by extraction with ether (Quirk et al., 1976). The purified LPS was stored in solution over chloroform at a concentration of approx. $6 \mathrm{mg} \mathrm{ml}^{-1}$.

Acid hydrolysis of LPS. The sidechain and core components were released from lipid A by hydrolysis of LPS (10$20 \mathrm{mg}$ ) with $4-8 \mathrm{ml} 0.01 \mathrm{M}-\mathrm{HCl}$ at $100^{\circ} \mathrm{C}$ for $70 \mathrm{~min}$. Lipid A was extracted with two portions of $n$-hexane. The aqueous residue was dried by rotary evaporation to remove $\mathrm{HCl}$, taken up in water and freed of insoluble protein by membrane filtration (Millipore; $0.45 \mu \mathrm{m}$ porosity). Sidechain and core components were separated on a column $(1.9 \times 51.0 \mathrm{~cm})$ of Sephadex G75 or G50 (fine grade; Pharmacia), using 0.05 M-pyridine/acetic acid buffer, pH 5.4 (Fensom \& Meadow, 1970) at a flow rate of $0.25 \mathrm{ml} \mathrm{min}^{-1}$. Fractions ( $2 \mathrm{ml}$ ) were analysed for carbohydrate and phosphate (see below). Peak fractions were pooled and concentrated by rotary evaporation.

Monosaccharide was completely released by heating LPS $\left(2.5 \mathrm{mg} \mathrm{ml}^{-1}\right)$ with $2 \mathrm{M}-\mathrm{HCl}$ for $20 \mathrm{~min}$ at $100^{\circ} \mathrm{C}$ (R. C. Hignett \& A. V. Quirk, unpublished observations). Monosaccharide was released from core or sidechain material by the same procedure.

LPS, or isolated lipid A, were totally hydrolysed with $6.1 \mathrm{M}-\mathrm{HCl}(2 \mathrm{ml}$ per $2.5 \mathrm{mg} \mathrm{sample})$ at $105^{\circ} \mathrm{C}$ for $4 \mathrm{~h}$ under $\mathbf{N}_{2}$ or $\mathrm{CO}_{2}$. After dilution with water, liberated fatty acids were extracted with ether, dried and esterified using diazomethane. The aqueous residue was dried to remove $\mathrm{HCl}$ as described above prior to further analysis.

Alkaline de-O-acylation of LPS. LPS $(10 \mathrm{mg})$ was de- $O$-acylated in alkali as described by Chester \& Meadow (1975) and chromatographed on a column of Sephadex G200. Fractions were analysed for carbohydrate and KDO (see below).

Methanolysis of LPS. Fatty acids were liberated from lipid A or LPS (1-5 mg) as their methyl esters by the method of Salkinoja-Salonen \& Boeck (1978). Methyl nonadecanoate $(0 \cdot 2 \mathrm{mg})$ was the internal standard.

Ester-bound acids were preferentially converted to their methyl esters by treatment of LPS with sodium methoxide (Rietschel et al., 1972). Amide-linked fatty acids were liberated from the ether-insoluble residue by subsequent treatment with $4 \mathrm{M}-\mathrm{KOH}$ for $5 \mathrm{~h}$ at $100^{\circ} \mathrm{C}$. After acidification with $1 \mathrm{M}-\mathrm{HCl}$, samples were extracted into ether, washed with water, dried and treated with diazomethane in ether.

Partial hydrolysis of LPS by phage A7. Phage A7 (3.3 $\times 10^{12}$ p.f.u., pelleted from a stock suspension in PYG by centrifugation at $40000 \mathrm{~g}$ for $1 \mathrm{~h}$, and washed once in water), was mixed with $5 \mathrm{mg} \mathrm{LPS}$ in $2 \mathrm{ml}$ water and incubated with mild agitation at $20^{\circ} \mathrm{C}$ for $2 \mathrm{~h}$. The digested LPS was fractionated at a flow rate of $0.6 \mathrm{ml} \mathrm{min}^{-1}$ on a column $(1.6 \times 41.0 \mathrm{~cm})$ of Sepharose 4B (Pharmacia) equilibrated with water. Fractions $(4 \mathrm{ml})$ were analysed for carbohydrate and phosphate. Peak fractions were pooled, reduced in volume and submitted to further analysis as detailed in Results.

Paper chromatography, TLC and electrophoresis. Sugars, aminosugars and amino acids were separated by descending chromatography on Whatman No. 1 paper using solvent $A$, butan-1-ol/pyridine/water $(6: 4: 3$, by vol.; 
Quirk et al., 1976), and by paper electrophoresis in 6.3\% (v/v) formic acid/13\%(v/v) acetic acid, pH $2 \cdot 0$. Samples were run for $90 \mathrm{~min}$ at $30 \mathrm{~V} \mathrm{~cm}^{-1}$. Amino compounds were also separated by two-dimensional TLC on cellulose plates (Whatman type CC41) using solvent B, propan-2-ol/formic acid/water $(20: 1: 5$, by vol.) followed by $\mathrm{C}$, tertbutanol/butan-2-one/ammonia/water $(5: 3: 1: 2$, by vol.). Sugars and aminosugars were detected using 4aminobenzoic acid reagent (Saini, 1966); amino compounds were visualized using ninhydrin (Dawson et al., 1969).

Methyl alkanoates were separated from methyl hydroxyalkanoates by TLC at $37^{\circ} \mathrm{C}$ on plates of silica gel $\mathrm{G}$ (Kieselgel G; Merck) developed successively with solvent D (chloroform/ethyl acetate; $4: 1, \mathrm{v} / \mathrm{v}$ ) for $7 \mathrm{~cm}$, and $\mathrm{E}$ (benzene) for $14 \mathrm{~cm}$ (Salkinoja-Salonen \& Boeck, 1978). Spots were visualized with ethanolic fluorescein (0.05\%, $\mathrm{w} / \mathrm{v})$, and were eluted with chloroform/methanol $(2: 1, \mathrm{v} / \mathrm{v})$.

Electrophoresis of LPS on cellulose acetate was done according to the method of Quirk et al. (1976). Electrophoresis of LPS on polyacrylamide gel slabs was done by the procedure of Laemmli (1970), and visualized using the silver stain of Tsai \& Frasch (1982). In some instances, LPS was visualized by the periodate-Schiff reaction, and protein by staining with Coomassie Brilliant Blue $\mathbf{R}$ (Hignett \& Quirk, 1979).

Amino compound analysis. The amino compounds obtained from the hydrolysis of approx. $5 \mathrm{mg}$ LPS, lipid A or polysaccharide (see above), were quantified in an automatic analyser (Locarte Co., London, UK), essentially as described by Chester et al. (1973), with norleucine $(0.5 \mu \mathrm{mol})$ as the internal standard.

GC of fatty acid methyl esters. Fatty acid methyl esters were analysed on two columns by flame ionization detection: (i), a Carbowax 20M SCOT splitless glass capillary $(0.5 \mathrm{~mm} \times 30 \mathrm{~m}$; Scientific Glass Engineering, UK) operated with temperature programming from $120^{\circ} \mathrm{C}$ to $200^{\circ} \mathrm{C}$ at $2{ }^{\circ} \mathrm{C} \mathrm{min}^{-1}$ and $\mathrm{N}_{2}\left(2.1 \mathrm{ml} \mathrm{min}^{-1}\right)$ as the carrier gas; (ii), a packed column $(3.2 \mathrm{~mm} \times 183 \mathrm{~cm})$ of $3 \%$ SP2100-DOH on 100/120 mesh Supelcoport (Supelco) operated with temperature programming from $150^{\circ} \mathrm{C}$ to $225^{\circ} \mathrm{C}$ at $2^{\circ} \mathrm{C} \mathrm{min}^{-1}$ and $\mathrm{N}_{2}\left(20 \mathrm{ml} \mathrm{min}^{-1}\right)$ as the carrier. Methyl esters of fatty acids were quantified by integration of the areas under peaks, taking the response factor as 1 on a weight basis in all cases (Rietschel et al., 1972), and using methyl nonadecanoate as the internal standard.

Estimations. Protein was determined on intact LPS by the Folin method using bovine serum albumin, fraction $\mathrm{V}$, as the standard. Nucleic acid was determined spectrophotometrically at $260 \mathrm{~nm}$ (Dawson et al., 1969). Total amino compounds were quantified with ninhydrin after hydrolysis of the sample in $6 \cdot 1 \mathrm{M}-$ or $2 \mathrm{M}-\mathrm{HCl}$ (Moore \& Stein, 1948), with L-alanine as standard. Total aminosugars (hexosamines) were determined colorimetrically (Rondle \& Morgan, 1955) after hydrolysis of the sample in $6 \cdot 1 \mathrm{M}-$ or $2 \mathrm{M}-\mathrm{HCl}$, with D-glucosamine as standard.

Total carbohydrate was determined by the phenol-sulphuric acid reaction (Dubois et al., 1956) against L-rhamnose as standard. Rhamnose and heptose were determined by the method of Osborn (1963), using D-mannoheptulose as the standard for the latter determination. KDO was determined on samples after acid hydrolysis by the method of Weissbach \& Hurwitz (1959) as modified by Osborn (1963). Glucose was determined colorimetrically with glucose oxidase (Sigma), after hydrolysis of samples with $2 \mathrm{M}-\mathrm{HCl}$.

Phosphate was determined by the method of Murphy \& Riley (1962) after oxidation of samples with $0.05 \mathrm{ml}$ conc. $\mathrm{H}_{2} \mathrm{SO}_{4}$ containing $1 \%(\mathrm{w} / \mathrm{v}) \mathrm{Se}$ and $0.05 \mathrm{ml}$ of 100 vol. $\mathrm{H}_{2} \mathrm{O}_{2}$ at $200{ }^{\circ} \mathrm{C}$ for $1 \mathrm{~h}$.

Calcium and magnesium were determined by atomic absorption spectroscopy, potassium by atomic emission spectroscopy.

\section{RESULTS AND DISCUSSION}

\section{Extraction and purity of LPS}

Quirk (1976) found that cultures of $P$. syringae pv. morsprunorum strain C28 grown on nutrient glycerol broth (NGB) tended to undergo lysis soon after entering stationary phase. In the present investigation this was avoided by growing the organism in modified Erikson's medium. However, LPS prepared from cells grown on NGB had been free of protein, but despite treatment with pronase, LPS extracted from cells grown on salts medium was contaminated with $1-2 \%(w / w)$ of tightly associated protein which, in the absence of SDS, migrated on polyacrylamide gels together with the LPS. The absorption spectrum of material after block electrophoresis typically displayed a shoulder at approx. $260 \mathrm{~nm}\left(A_{253}^{0.1 \%}=0 \cdot 2-0 \cdot 3\right)$, indicating the presence of approx. $0.5 \%(\mathrm{w} / \mathrm{w})$ nucleic acid. Although electrophoresis in SDS on cellulose acetate did not reveal any extra lipid bands, purified LPS also appeared to contain some free long chain fatty acids (see later). Preparations were, however, free of $\alpha, \varepsilon$-diaminopimelic acid and thus were not contaminated by peptidoglycan.

The yield of purified LPS was approx. $40 \mathrm{mg}$ ( $\mathrm{g}$ acetone-dried cells) $)^{-1}$. 
Table 1. Composition of lipopolysaccharide from $P$. syringae pv. morsprunorum C28

\begin{abstract}
Assays were performed according to the procedures given in Methods. Fatty acids were determined by weighing the ether-extractable oil from a $6 \cdot 1 \mathrm{M}-\mathrm{HCl}$ hydrolysate of LPS. Lipid A was determined by weighing the hexane-extractable precipitate from LPS hydrolysed in $2 \mathrm{M}-\mathrm{HCl}$ for $20 \mathrm{~min}$.
\end{abstract}

\begin{tabular}{|c|c|c|}
\hline Component & Analysis 1 & Analysis 2 \\
\hline Potassium & 0.03 & 0.004 \\
\hline Calcium & 0.31 & 0.48 \\
\hline Magnesium & 0.28 & $0 \cdot 20$ \\
\hline Phosphorus & $1 \cdot 26$ & 1.38 \\
\hline Rhamnose & $1 \cdot 40$ & 1.90 \\
\hline Glucose & 0.20 & 0.25 \\
\hline Heptose & $0 \cdot 12$ & 0.07 \\
\hline KDO & 0.09 & $0 \cdot 10$ \\
\hline Alanine & $0 \cdot 13$ & $0 \cdot 19$ \\
\hline Glucosamine & ND & 0.38 \\
\hline Galactosamine & ND & $0 \cdot 17$ \\
\hline Aminosugar phosphates & ND & 0.08 \\
\hline Ethanolamine & ND & 0.06 \\
\hline Total carbohydrate (rhamnose equivalents) & & $2 \cdot 30$ \\
\hline Total amino compounds (alanine equivalents) & 1.25 & $1 \cdot 50$ \\
\hline Total amino sugars (glucosamine equivalents) & $0 \cdot 30$ & $0 \cdot 38$ \\
\hline & \multicolumn{2}{|c|}{ Amount $\left[\mu \mathrm{g}(\mathrm{mg} \mathrm{LPS})^{-1}\right]$} \\
\hline Fatty acids & 90 & 118 \\
\hline Lipid A & 200 & 290 \\
\hline Protein & 19 & ND \\
\hline
\end{tabular}

ND, Not determined.

\title{
Analysis of whole LPS
}

Cultures of strain C28 show a pronounced variation in colonial morphology which may be associated with changes in the composition of the LPS. Quirk et al. (1976) found that the composition of LPS extracted from different clones of C28 fluctuated widely in respect of the rhamnose:glucose ratio. In our experience too, the composition of LPS varied in this and in other respects, and we encountered one form of the organism from which no LPS could be extracted at all. We have therefore attempted to minimize variation by preparing LPS from cultures made from a single set of lyophilisates. Despite this precaution, differences were still encountered; therefore data are presented from two independent analytical studies.

Hydrolysis of LPS with $2 \mathrm{M}-\mathrm{HCl}$ at $100^{\circ} \mathrm{C}$ for $20 \mathrm{~min}$ gave quantitative release of the lipid A, which amounted to $20 \%$ ( $29 \%$ in the second analysis) of the dry weight of the original LPS. The water-soluble residue accounted for $78 \%(70 \%)$ of the original dry weight. In agreement with Quirk et al. (1976), paper chromatography of the water-soluble material in solvent A revealed only rhamnose and glucose. In this solvent, heptose migrates with glucose and its presence (see below) was therefore masked.

The aqueous residue from a total acid hydrolysis of LPS was examined by paper electrophoresis, by paper chromatography in solvent A and by TLC on cellulose plates using solvents $B$ and $C$. Major ninhydrin- and 4-aminobenzoate-positive spots were seen, corresponding in $R_{F}$ with glucosamine and galactosamine (separable only in solvent A). Two major ninhydrin-positive spots were identified with alanine and ethanolamine; several weaker spots corresponding with other amino acids were also visualized.

Table 1 shows the composition of the LPS analysed in this investigation. The qualitative differences from the earlier findings of Quirk et al. (1976) lay in the detection of heptose and protein in these samples. The remaining differences were quantitative. In particular, the amounts of rhamnose and glucose differed, and whereas the maximal rhamnose :glucose ratio was found by Quirk et al. to be $4: 1$, the highest recorded here was 7.6:1. The content of amino 
Table 2. Composition of lipid A from lipopolysaccharide of $P$. syringae pv. morsprunorum $C 28$

Lipid A was derived from LPS by hydrolysis in $2 \mathrm{M}-\mathrm{HCl}$ at $100^{\circ} \mathrm{C}$ for $20 \mathrm{~min}$, and extracted quantitatively in $n$-hexane. Analyses were performed according to the procedures given in Methods. Fatty acid methyl esters were analysed by GC using a $0.5 \mathrm{~mm} \times 30 \mathrm{~m}$ Carbowax $20 \mathrm{M}$ SCOT. Analyses performed on intact LPS gave closely similar results. Glucosamine in analysis 1 was determined by the 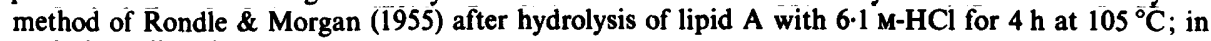 analysis 2 all amino compounds were determined by auto-analysis.

\begin{tabular}{|c|c|c|c|c|}
\hline \multirow[b]{2}{*}{ Component } & \multicolumn{2}{|c|}{ Analysis 1} & \multicolumn{2}{|c|}{ Analysis 2} \\
\hline & $\begin{array}{c}\text { Amount } \\
{\left[\mu \mathrm{mol}(\mathrm{mg} \mathrm{LPS})^{-1}\right]}\end{array}$ & $\begin{array}{c}\text { Ratios } \\
(\mathrm{GlcN}=1)\end{array}$ & $\begin{array}{c}\text { Amount } \\
{\left[\mu \mathrm{mol}(\mathrm{mg} \mathrm{LPS})^{-1}\right]}\end{array}$ & $\begin{array}{c}\text { Ratios } \\
(\text { GlcN = 1) }\end{array}$ \\
\hline $12: 0$ & $0 \cdot 16$ & 0.99 & 0.18 & $1 \cdot 12$ \\
\hline $3 \mathrm{HO}-10: 0$ & $0 \cdot 15$ & 0.96 & $0 \cdot 14$ & 0.88 \\
\hline $2 \mathrm{HO}-12: 0$ & 0.07 & 0.42 & $0 \cdot 18$ & $1 \cdot 12$ \\
\hline $3 \mathrm{HO}-12: 0$ & 0.07 & 0.46 & 0.07 & 0.44 \\
\hline Glucosamine (GlcN) & $0 \cdot 16$ & 1.00 & $0 \cdot 16$ & 1.00 \\
\hline Phosphorus & $0 \cdot 18$ & $1 \cdot 20$ & ND & ND \\
\hline Amino-sugar phosphate & ND & & 0.04 & \\
\hline Galactosamine & ND & & 0.02 & \\
\hline Alanine & ND & & 0.02 & \\
\hline Ethanolamine & ND & & 0.01 & \\
\hline
\end{tabular}

ND, Not determined.

compounds (expressed as alanine equivalents) was found to be approximately fourfold greater in our analysis, probably attributable to the protein contaminant.

Quantitative estimates of the glucosamine, galactosamine, ethanolamine and alanine content were obtained by autoanalysis. In addition, there were small quantities of the full range of protein amino acids, and an unidentified compound, $X$, which eluted between galactosamine and histidine and which amounted to $0.035 \mu \mathrm{mol}$ norleucine equivalents (mg LPS) ${ }^{-1}$. Atomic absorption and emission spectroscopy revealed the presence of approximately equimolar amounts of $\mathrm{Ca}$ and $\mathrm{Mg}$, and a trace of $\mathrm{K}$. The fatty acid content was determined gravimetrically on samples of the ether-extractable material from LPS after hydrolysis with $6 \cdot 1 \mathrm{M}-\mathrm{HCl}$. Its composition is described in the following section.

\section{Composition of lipid $A$}

Lipid A obtained by the hydrolysis of LPS with $2 \mathrm{M}-\mathrm{HCl}$ at $100^{\circ} \mathrm{C}$ for $20 \mathrm{~min}$ contained phosphate and glucosamine, which was identified by autoanalysis and by paper chromatography in solvent A. Lesser quantities of galactosamine and some amino acids were also detected (Table 2).

Fatty acids were liberated from lipid A or from intact LPS as their methyl esters by using methanolic sulphuric acid. Gas chromatography of the transmethylation products revealed four major peaks that co-chromatographed on both Carbowax 20M and SP2100-DOH with methyl dodecanoate, methyl 3-hydroxydecanoate, methyl 2-hydroxydodecanoate and methyl 3hydroxydodecanoate, and a minor peak that corresponded with methyl hexadecanoate. Prior separation of methyl dodecanoate from the methyl esters of the hydroxyacids was achieved by TLC on silica gel G plates developed successively in solvents D and E. Treatment of LPS with sodium methoxide released dodecanoic acid, 3-hydroxydecanoic acid and 2-hydroxydodecanoic acid, which were therefore ester-linked; 3-hydroxydodecanoic acid was released from the partially degraded LPS only by subsequent treatment with $4 \mathrm{M}-\mathrm{KOH}$, and was therefore amidelinked.

Hydrolysis of LPS in $6.1 \mathrm{M}-\mathrm{HCl}$ followed by methylation of the ether-extracted free fatty acids using diazomethane gave a relatively greater recovery of methyl hexadecanoate, and two new unidentified peaks emerging close to methyl dodecanoate. Treatment with diazomethane of the ether-extracted oil obtained from transmethylation using methanolic sulphuric acid also gave a significant increase in the amounts recovered of these esters. It would therefore appear that LPS was contaminated with free hexadecanoic acid and two other acids. 


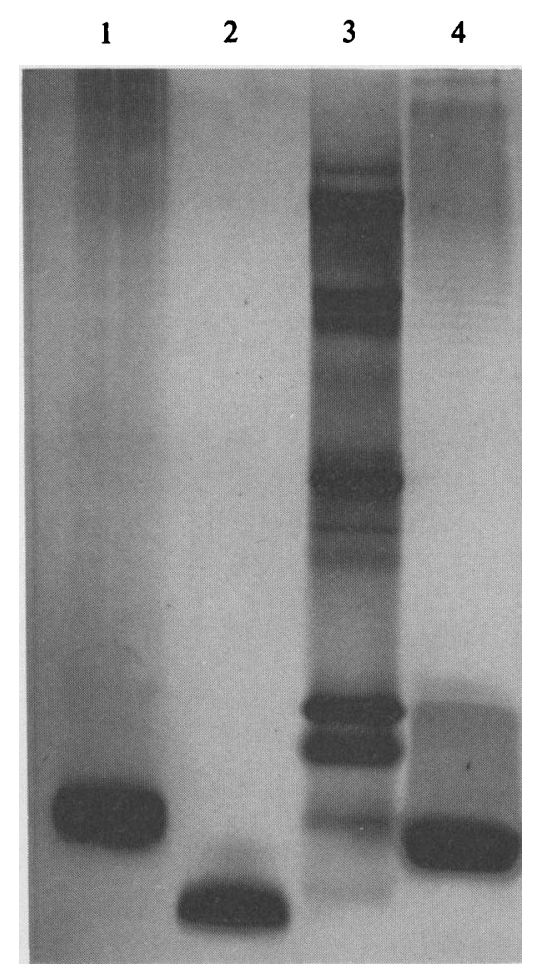

Fig. 1. Polyacrylamide gel electrophoresis of SDS-treated LPS from $\boldsymbol{P}$. syringae pv. morsprunorum C28. LPS or protein samples were denatured by treatment with SDS according to the procedure of Laemmli (1970) and loaded onto a $12 \%$ separating polyacrylamide gel slab $(20 \mathrm{~cm} \times 16 \mathrm{~cm} \times 1 \mathrm{~mm})$ surmounted by $3 \%$ stacking gel. The gel was run for $4 \mathrm{~h}$ at $20 \mathrm{~mA}$ in $0.025 \mathrm{M}$-Tris/0.192 M-glycine buffer, pH 8.3, containing $0 \cdot 1 \%(\mathrm{v} / \mathrm{v}) \mathrm{SDS}$, then fixed and stained with silver as described in Methods. (1) R-LPS of $E$. coli ATCC 12408, $5 \mu \mathrm{g}$; (2) R-LPS of $S$. minnesota MR595, $10 \mu \mathrm{g}$; (3) protein standards mixture (5 $\mu \mathrm{l})$ containing proteins of the following molecular weights : 78000, 66250,45000, 25700, 17200, 12300; (4) LPS of strain C28, 15 $\mathrm{g}$. The origins are situated at the top of the photograph.

Glucosamine, phosphate, dodecanoic acid and 3-hydroxydecanoic acid were present in lipid $A$ in approximately equimolar amounts together with half the molar quantity of 3hydroxydodecanoic acid (Table 2). The quantity of 2-hydroxydodecanoic acid was variable.

This lipid $\mathrm{A}$ is therefore similar to that of other pseudomonad species. The four major fatty acids are the same as those found in lipid A from P. aeruginosa (Hancock et al., 1970; Wilkinson \& Galbraith, 1975), and P. syncyanea (Wilkinson et al., 1973). As is usual in pseudomonads, 3hydroxydodecanoic acid is the amide-linked substituent on glucosamine rather than 3hydroxytetradecanoic acid, the normal component of enterobacterial LPS.

\section{Hydrolysis of LPS under mildly acidic conditions}

Analysis of intact C28 LPS by SDS-PAGE revealed a fast-running component, whose mobility matched that of the rough LPS from $E$. coli ATCC 12408, together with a series of slower-moving bands concentrated towards the origin (Fig. 1). This pattern is consistent with that expected of a mixture of rough and smooth lipopolysaccharides, the latter bearing sidechains of varying length.

Mild acid hydrolysis was used to release intact core and sidechain carbohydrates from the lipid A so as to investigate the molecular structure of the LPS. In preliminary experiments, the release of Lipid A by $1 \%$ acetic acid (Fensom \& Meadow, 1970) was sometimes incomplete even after $4 \mathrm{~h}$ at $100^{\circ} \mathrm{C}$. However, hydrolysis in the presence of $0.01 \mathrm{M}-\mathrm{HCl}$ (Chester et al., 1973) was complete in $70 \mathrm{~min}$, and accordingly this procedure was used routinely. After removal of 


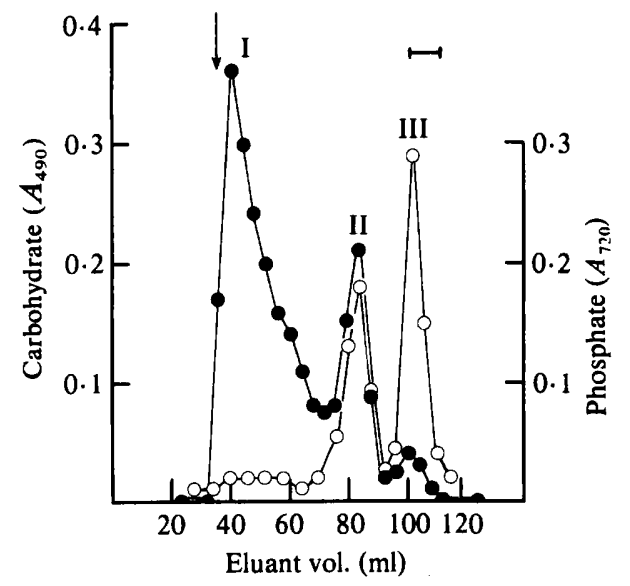

Fig. 2. Fractionation on Sephadex G75 of carbohydrate obtained from the hydrolysis with $0.01 \mathrm{M}-\mathrm{HCl}$ of LPS from P. syringae pv. morsprunorum C28. LPS $(16.5 \mathrm{mg})$ was hydrolysed with $0.01 \mathrm{M}-\mathrm{HCl}$, and the carbohydrate $(12.9 \mathrm{mg})$ was fractionated on a column of Sephadex G75. Volumes of $0 \cdot 1 \mathrm{ml}$ were analysed for total carbohydrate $(O)$, and for total phosphate $(O)$. For full experimental details, refer to Methods. Roman numerals I, II, III refer to the peak materials later pooled. Vertical arrow and horizontal bar indicate elution volumes of blue dextran and $\mathrm{Cl}^{-}$respectively.

insoluble material, the aqueous fraction gave three peaks by gel permeation chromatography on Sephadex G75 (Fig. 2). The first peak (I), emerged with the void volume and consisted of carbohydrate together with very little phosphate. Peak II contained both components. Peak III, which emerged with the totally included volume, contained phosphate but very little carbohydrate. Fractions containing peak material were pooled for further analysis; the results are given in Table 3.

Peak I material gave a coloured product in the phenol-sulphuric acid reaction whose spectrum $\left(\lambda_{\max }=480 \mathrm{~nm}\right)$ matched that of authentic rhamnose. Paper chromatography of a $2 \mathrm{M}-\mathrm{HCl}$ hydrolysate of peak I material in solvent A revealed only rhamnose. This material also contained $60 \%$ of the compound X content of intact LPS, but only very small quantities of phosphate, glucose, KDO, aminosugars and other ninhydrin-reactive compounds, and it is concluded that, like the sidechain fraction of $P$. cepacia (Knirel et al., 1980), it was essentially a simple rhamnan.

Peak II contained rhamnose, glucose and heptose together with glucosamine and galactosamine, amino acids (principally alanine), phosphate, a little KDO and a trace of compound $\mathrm{X}$. Ignoring the last two components, the composition of peak II material approximated to that of a notional octa- or nonasaccharide, $\mathrm{Glc}_{2} \cdot \mathrm{Rha}_{1-2}$. Hep. GlcN 2 . Ala. $\mathrm{P}_{3}$ (where $\mathbf{P}=$ phosphate). The core peak was not always well separated from the high molecular weight peak, which may account for the variation seen in the rhamnose :glucose ratio. With the exception of glucosamine, these components are also found in the core of $P$. alcaligenes LPS (Lomax et al., 1974) and of $P$. aeruginosa LPS, the structure of which was recently elucidated (Drewry et al., 1975; Rowe \& Meadow, 1983). Peak III contained KDO, phosphate and ethanolamine.

From their molecular weight and residue composition, the three peaks are thought to have represented respectively the complete polysaccharide (sidechain-core), the core, and the link regions of the intact LPS molecule. To confirm this interpretation, LPS was de- $O$-acylated in ethanolic alkali according to the method of Chester \& Meadow (1975) and submitted to chromatography on Sephadex G200. All the applied carbohydrate (as detected by the phenolsulphuric acid reaction) and KDO eluted together in a single broad peak. In intact LPS the rhamnose is therefore covalently joined to the KDO. However, since SDS-PAGE had indicated that the LPS was a mixture of smooth and rough species, two peaks of KDO-rich material were expected, only one of which should also have contained the rhamnan. Apparently, gel permeation chromatography does not always give a clear separation of the de- $O$-acylated $S$ - and R-LPS. 
(1)

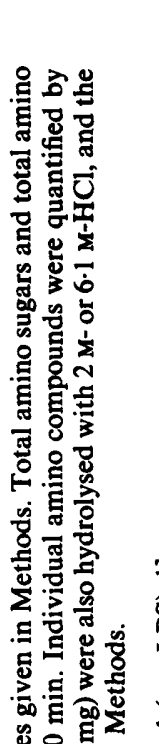

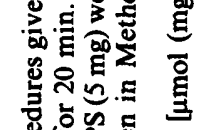

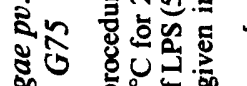

年 80

के

रू क्षे

行总记志

ร

结

๖ ญ्ष

总吉焉

눙형

응. 농

.

言究它

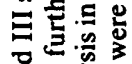

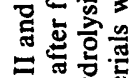

골

ऽ

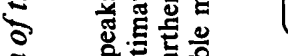

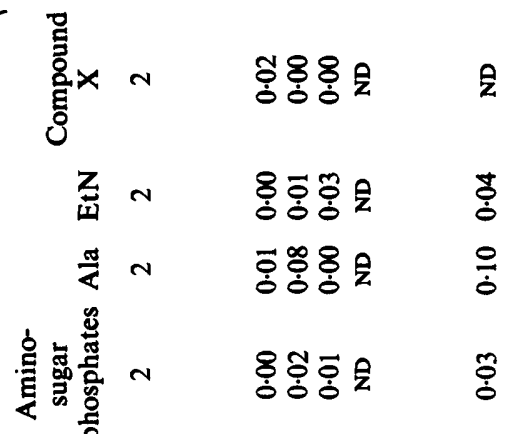

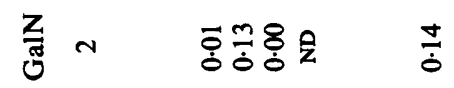

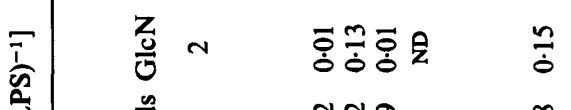

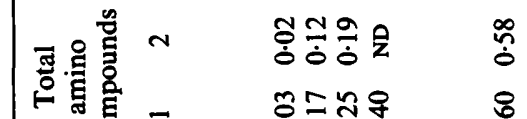

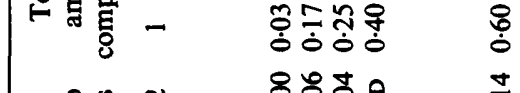

节 \{

颉总总

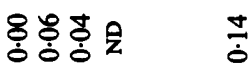

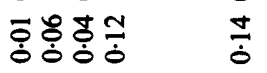

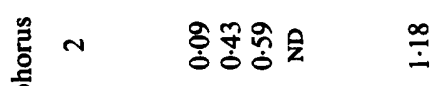

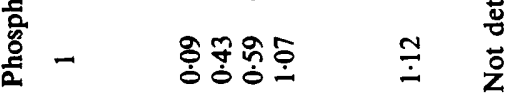

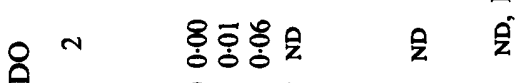

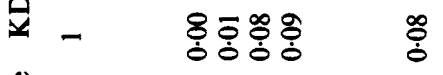

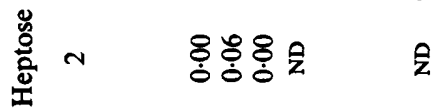

㑒娄

ह

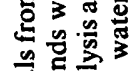

帚

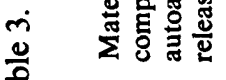

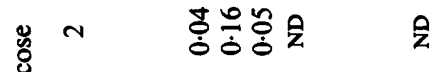

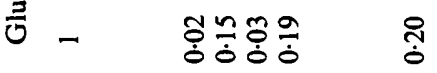

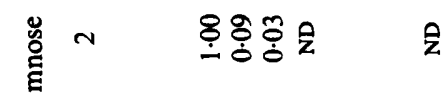

蛋 -

望市

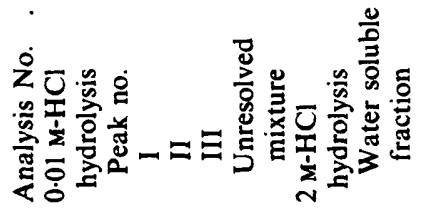




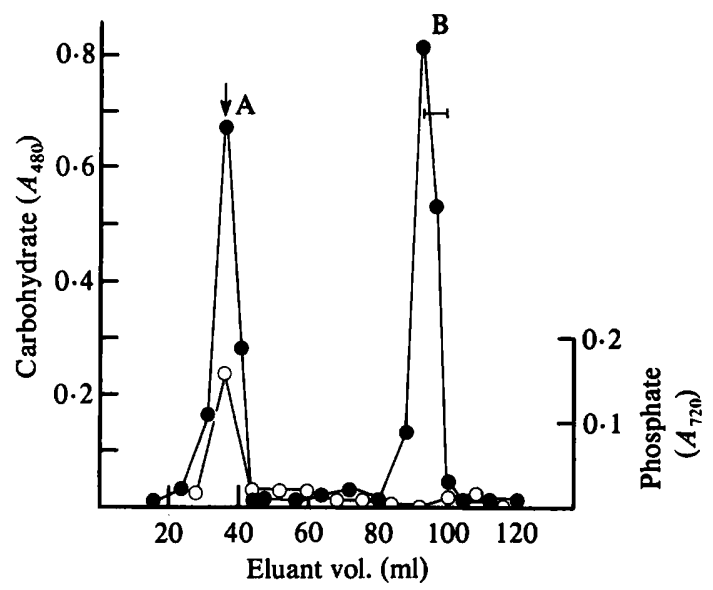

Fig. 3. Elution profile on Sepharose 4B of material derived from LPS of $P$. syringae pv. morsprunorum C28 following incubation with phage A7. Phage A7-LPS incubation mixture was fractionated on a column of Sepharose 4B. Volumes of $0.2 \mathrm{ml}$ were taken for total carbohydrate assay (O), and $0.5 \mathrm{ml}$ volumes were assayed for total phosphate $(O)$. For full experimental details, refer to Methods. Letters $A$ and $B$ refer to the peak materials later pooled. Vertical arrow and horizontal bar indicate elution volumes of blue dextran and $\mathrm{Cl}^{-}$, respectively.

Since it is now apparent that rhamnose is concentrated mainly in the sidechain of this LPS, the fluctuations in the content of this sugar mentioned earlier are probably attributable to variations either in the length of the sidechains or in the ratio of S-LPS to R-LPS.

\section{Interaction of phage A7 with LPS}

Quirk et al. (1976) demonstrated that purified LPS of strain C28 bound phage A7 and inactivated it efficiently at low concentration $\left(\mathrm{PI}_{50} \simeq 0.05 \mu \mathrm{g} \mathrm{ml}^{-1}\right.$ for a suspension containing $10^{4}$ p.f.u. of phage $A 7 \mathrm{ml}^{-1}$ ). In the present investigation, a value for $\mathrm{PI}_{50}$ of $0.5 \mu \mathrm{g} \mathrm{ml}^{-1}$ was found. By contrast, only weak inactivation $\left(\mathrm{PI}_{50}=335 \mu \mathrm{g} \mathrm{ml}^{-1}\right)$ was observed with the mixed carbohydrate products resulting from hydrolysis of the LPS with $0.01 \mathrm{M}-\mathrm{HCl}$.

Several other phages that are bound by isolated S-LPS possess a glycosidase located in their tail fibres that catalyses the release of sidechain carbohydrate as oligosaccharide (Lindberg, 1977; Wright et al., 1980). To see whether phage A7 displayed such activity, washed particles $\left(3.3 \times 10^{12}\right.$ p.f.u. $)$ were gently agitated with LPS $(5 \mathrm{mg})$ in water $(2 \mathrm{ml})$ at room temperature for $2 \mathrm{~h}$. Column chromatography of the product on Sepharose 4B yielded two peaks (Fig. 3). The first, peak A, emerging with the void volume, contained carbohydrate and phosphate, and resembled the parent LPS in giving pronounced light-scatter. The second, peak B, was totally included and contained only carbohydrate.

A sample $(1.47 \mathrm{mg})$ of material from peak A was hydrolysed in $0.01 \mathrm{M}-\mathrm{HCl}$ at $100^{\circ} \mathrm{C}$. Precipitation of an ether-soluble lipid A was much more rapid than with intact LPS, being complete within $5 \mathrm{~min}$, but heating was continued for $70 \mathrm{~min}$ as had been done for the hydrolysis of the parent LPS. After removal of lipid $\mathrm{A}$ and $\mathrm{HCl}$, the aqueous residue was applied to a column $(1.9 \times 44.0 \mathrm{~cm})$ of Sephadex G50 and eluted with $0.05 \mathrm{M}$-pyridine/acetic acid buffer, pH 5.4 at $0.25 \mathrm{ml} \mathrm{min}^{-1}$ (Fig. $4 a$ ). Fractions were collected and analysed for total carbohydrate and phosphate. Nothing was eluted with the void volume, but two peaks emerged (PII and PIII) in the same positions as peaks II and III obtained from the mild acid hydrolysis of the parent LPS. The composition of these peaks was closely similar to that of II and III (Table 4).

A sample $(0.40 \mathrm{mg})$ of the material from peak B when submitted to chromatography on Sephadex G50 emerged in one asymmetrical peak a little ahead of the totally included volume (Fig. $4 b$ ). Paper chromatography of the material in solvent A after hydrolysis with $2 \mathrm{M}-\mathrm{HCl}$ for $20 \mathrm{~min}$ at $100^{\circ} \mathrm{C}$ revealed the presence of rhamnose as the only sugar. The amount of rhamnose liberated by phage action (Table 4) was the same as the weight of sidechain rhamnose (peak I) 

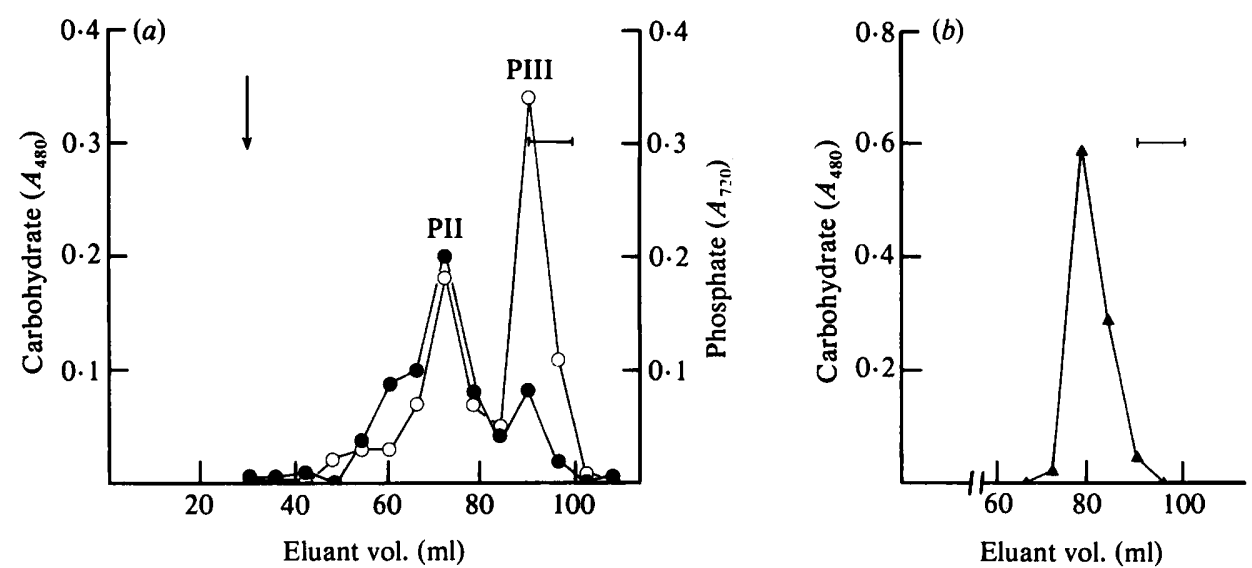

Fig. 4. Elution profiles on Sephadex G50 of carbohydrate fractions derived from LPS of $P$. syringae pv. morsprunorum $\mathrm{C} 28$ by action of phage A7 rhamnanase. (a) Eluate material of peak A (Fig. 3) was hydrolysed in $0.01 \mathrm{M}-\mathrm{HCl}$ and fractionated on Sephadex $\mathrm{G} 50$ (3 ml fractions). Volumes of $1 \mathrm{ml}$ were analysed for carbohydrate ( $O$ ), and for phosphate $(O)$. Designations PII and PIII refer to the materials from acid hydrolysed peak B later pooled. (b) Eluate material of peak B (Fig. 3) was fractionated on Sephadex G50. Volumes of $1 \mathrm{ml}$ were assayed for carbohydrate (A). For full experimental details, refer to Methods and Results. Vertical arrow and horizontal bars indicate elution volumes of blue dextran and $\mathrm{Cl}^{-}$respectively.

Table 4. Composition of the carbohydrate fractions derived from LPS of P. syringae pv. morsprunorum $C 28$ by action of phage A7 rhamnanase

The material from peak B (Fig. 3) was analysed directly according to the procedures given in Methods. Peak A material (Fig. 3) was acid-hydrolysed and fractionated on Sephadex G50 to yield the two peaks PII and PIII (Fig. 4a), which were analysed according to the procedures given in Methods. Total amino sugars and total amino compounds were estimated after further hydrolysis of samples in $2 \mathrm{M}-\mathrm{HCl}$ at $100^{\circ} \mathrm{C}$ for $20 \mathrm{~min}$.

\begin{tabular}{|c|c|c|c|c|c|c|}
\hline & \multicolumn{6}{|c|}{ Amount of component $\left[\mu \mathrm{mol}(\mathrm{mg} \mathrm{LPS})^{-1}\right]$} \\
\hline & Rhamnose & Glucose & Heptose & KDO & $\begin{array}{l}\text { Total } \\
\text { amino } \\
\text { sugars }\end{array}$ & $\begin{array}{c}\text { Total } \\
\text { amino } \\
\text { compounds }\end{array}$ \\
\hline $\begin{array}{l}\text { Peak B } \\
0.01 \mathrm{M}-\mathrm{HCl} \text { hydrolysis products of peak A }\end{array}$ & 1.39 & 0.00 & 0.00 & 0.001 & 0.01 & $0 \cdot 29$ \\
\hline PII & $0 \cdot 23$ & $0 \cdot 105$ & 0.044 & 0.005 & 0.063 & 0.40 \\
\hline
\end{tabular}

liberated by mild acid hydrolysis (Table 3). Glucose, KDO, heptose and aminosugar (ElsonMorgan-positive material) were absent, but some ninhydrin-reactive material was detected (Table 4). Phage A7 therefore possesses a rhamnanase that releases the sidechain from LPS as oligosaccharide, leaving only the core attached to the lipid A. Molar ratios of the residues rhamnose, glucose, heptose, aminosugar and KDO in peak PII material were closely similar to those in peak II of the acid hydrolysate, with the exception that the material derived by phage treatment contained approx. 2-4 times as much rhamnose. Furthermore, the unknown compound $\mathrm{X}$ was now detected in the core-derived fraction of the phage digestion product rather than in the sidechain material. In phage-catalysed hydrolysis, the process of sidechain digestion probably halts at some point distal to the location of compound $\mathrm{X}$ in the sidechain-core polysaccharide.

The role of LPS from strain C28 as a phage receptor and its partial digestion by a viral enzyme is comparable with several well-documented instances of similar interactions amongst the LPSbinding phages of the Enterobacteriaceae. The Salmonella phages $\varepsilon^{15}, \varepsilon^{34}$ and P22; the 
Escherichia phage $\Omega 8$ and the Shigella phage Sf6 all bind to the core or lipid A region of smooth LPS, having removed the $\mathrm{O}$-antigen as oligosaccharide fragments, by the repetitive action of a specific glycosidase borne on the phage tail (Wright et al., 1980).

The site of action and specificity of these phage enzymes has been established. In particular, $\varepsilon^{15}, \mathrm{P} 22$ and Sf6 share the distinction with A7 of possession of rhamnosidases that recognize differing substitution patterns in residues. The rhamnanase of A7 hydrolyses the sidechain of C28 LPS, leaving intact a core region of approximately the same size as that derived from the LPS by acid hydrolysis, though the recovery of a relatively greater amount of rhamnose in the core would be consistent with the enzymic cleavage halting at a point distal to the terminus of unsubstituted core. As with many of the phages of the enterobacteria (Wright et al., 1980), the final binding site for A7 within the residual core-lipid A region is not known and was not found in the carbohydrate liberated by mild acid hydrolysis of intact LPS. The structure of the sidechain, the site of cleavage of the phage A7 rhamnanase and the nature of the oligosaccharide product have been characterized and will be the subject of further communications.

Other Pseudomonas phages, for example E79 (Rowe \& Meadow, 1983), $\phi$ PLS1, $\phi$ PLS44 and $\phi$ PLS27 (Jarrell \& Kropinski, 1981), are known to utilize LPS as their binding site, but there is no evidence that any of these display hydrolytic activity towards O-antigen. Bartell et al. (1968) described phage 2 of $P$. aeruginosa $\mathrm{BI}$ that released hexosamines from a polysaccharide obtained from bacterial cells. Later work (Castillo \& Bartell, 1976) revealed that the phage also bound to isolated lipopolysaccharide with the concomitant release of amino sugars.

The composition and structure of LPS from other virulent and avirulent cherry and plum isolates of $P$. syringae pv. morsprunorum, and LPS of the pv. syringae, will be described in further communications.

S.E.Z. was supported by a SERC CASE Studentship. A.R.W.S. is grateful to Thames Polytechnic for a period of sabbatical leave in connection with this work. We also wish to thank the following: Dr C. M. E. Garrett for source cultures; Dr D. Austin and Mr J. Allen for helpful discussion of GC methods; Mr T. Samuelson for atomic absorption and emission spectroscopy; Mr T. C. Ray for developing the autoanalysis programme; Dr Elizabeth Work and Dr M. Nurminen for authentic rough lipopolysaccharide; Dr S. G. Wilkinson for gifts of authentic hydroxylated fatty acids, and Dr Pauline Meadow for helpful discussion and gifts of authentic acids.

\section{REFERENCES}

Bartell, P. F., LAM, G. K. H. \& OrR, T. E. (1968). Purification and properties of polysaccharide depolymerase associated with phage-infected Pseudomonas aeruginosa. Journal of Biological Chemistry 243, 2077-2080.

Bauchop, T. \& ElsDen, S. R. (1960). The growth of micro-organisms in relation to their energy supply. Journal of General Microbiology 23, 457-469.

Castillo, F. J. \& Bartell, P. F. (1976). Localization and functional role of Pseudomonas bacteriophage 2 depolymerase. Journal of Virology 18, 701-708.

Chester, I. R. \& Meadow, P. M. (1975). Heterogeneity of the lipopolysaccharide from Pseudomonas aeruginosa. European Journal of Biochemistry 58, 273282.

Chester, I. R., Meadow, P. M. \& Pitt, T. (1973). The relationship between the $\mathrm{O}$-antigenic lipopolysaccharides and serological specificity in strains of Pseudomonas aeruginosa of different O-serotypes. Journal of General Microbiology 78, 305-318.

Crosse, J. E. (1959). Bacterial canker of stone-fruits. IV. Investigation of a method for measuring the inoculum potential of cherry trees. Annals of Applied Biology 47, 306-317.

Crosse, J. E. \& Garrett, C. M. E. (1963). Studies on the bacteriophagy of Pseudomonas morsprunorum,
Ps. syringue and related organisms. Journal of Applied Bacteriology 26, 159-177.

Crosse, J. E. \& Garrett, C. M. E. (1970). Pathogenicity of Pseudomonas morsprunorum in relation to host specificity. Journal of General Microbiology 62, 315327.

Dawson, R. M. C., Elliott, E. C., Elliott, W. H. \& JONES, K. M. (1969). Data for Biochemical Research, 2nd edn. Oxford: University Press.

Drewry, D. T., Symes, K. C., Gray, G. W. \& WILkINSON, S. G. (1975). Studies of polysaccharide fractions from the lipopolysaccharide of Pseudomonas aeruginosa NCTC 1999. Biochemical Journal 149, 93-106.

Dubois, M., Gilles, K. A., Hamilton, J. K., Rebers, P. A. \& SMITH, F. (1956). Colorimetric method for determination of sugars and related substances. Analytical Chemistry 28, 350-356.

ERIKSON, D. (1945). Certain aspects of resistance of plum trees to bacterial canker. Annals of Applied Biology 32, 44-52.

Fensom, A. H. \& Meadow, P. M. (1970). Evidence for two regions in the polysaccharide moiety of the lipopolysaccharide of Pseudomonas aeruginosa 8602. FEBS Letters 9, 81-84.

Freigoun, S. O. \& Crosse, J. E. (1975). Host relations 
and distribution of a physiological and pathological variant of Pseudomonas morsprunorum. Annals of Applied Biology 81, 317-330.

Garrett, C. M. E., Crosse, J. E. \& Sletten, A. (1974). Relations between phage sensitivity and virulence in Pseudomonas morsprunorum. Journal of General Microbiology 80, 475-483.

Garrett, C. M. E., Panagopoulos, C. G. \& Crosse, J. E. (1966). Comparison of plant pathogenic pseudomonads from fruit trees. Journal of Applied Bacteriology 29, 342-356.

Hancock, I. C., Humphreys, G. O. \& Meadow, P. M. (1970). Characterization of the hydroxy acids of Pseudomonas aeruginosa 8602. Biochimica et biophysica acta 202, 389-391.

Hignetr, R. C. \& QuiRK, A. V. (1979). Properties of phytotoxic cell-wall components of plant pathogenic pseudomonads. Journal of General Microbiology 110 , $77-81$.

Jarrell, K. F. \& Kropinski, A. M. (1981). Pseudomonas aeruginosa bacteriophage $\phi$ PLS27-lipopolysaccharide interactions. Journal of Virology 40, 411420.

KLEMENT, Z. (1963). Rapid detection of phytopathogenicity of phytopathogenic pseudomonads. Nature, London 199, 299-300.

KNIREl, Y. A., Shashkov, A. S., Dmitriev, B. A., KOCHETKOV, N. K., KasYaNChUK, N. V. \& ZAKHAROVA, I. Y. (1980). Antigenic polysaccharides of bacteria. II. The structure and ${ }^{13} \mathrm{C}$-NMR spectrum of O-specific polysaccharide from Pseudomonas cepacia. Bioorganischeskaya Khimiya 6, 1851-1859.

KnoX, K. W., Cullen, J. \& Work, E. (1967). An extracellular lipopolysaccharide-phospholipid-protein complex produced by Escherichia coli grown under lysine-limiting conditions. Biochemical Journal 103, 192-201.

LAEMMLI, U. K. (1970). Cleavage of structural proteins during the assembly of the head of bacteriophage $T 4$. Nature, London 227, 680-685.

LINDBERG, A. A. (1977). Bacterial surface carbohydrates and bacteriophage adsorption. In Surface Carbohydrates of the Prokaryote Cell, pp. 289-356. Edited by I. Sutherland. London: Academic Press.

LomaX, J. A., Gray, G. W. \& Wilkinson, S. G. (1974). Studies of the polysaccharide fraction from the lipopolysaccharide of Pseudomonas alcaligenes. Biochemical Journal 139, 633-643.

Lüderitz, O., Galanos, C., Risse, H. J., RuschmanN, E., SCHLecht, S., Schmidt, G., Schule-HolthaUSEN, H., Wheat, R., Westphal, O. \& SchlossHARDT, J. (1966). Structural relationships of Salmonella and $\mathrm{R}$ antigens. Annals of the New York Academy of Sciences 133, 349-374.

MOORE, S. \& SteIN, W. H. (1948). Photometric ninhydrin method for use in the chromatography of amino acids. Journal of Biological Chemistry 176, 367-388.

MURPhY, J. \& RiLEY, J. P. (1962). A modified single solution method for the determination of phosphate in natural waters. Analytica chimica acta 27, 31-36.
Osborn, M. J. (1963). Studies on the Gram-negative cell wall. I. Evidence for the role of 2-keto-3deoxyoctonate in the lipopolysaccharide of Salmonella typhimurium. Proceedings of the National Academy of Sciences of the United States of America 50, 499-506.

Quirk, A. V. (1976). Cell wall components of Pseudomonas morsprunorum (Wormald) and their role in pathogenicity. PhD thesis, University of London.

QUIRK, A. V., SLETTEN, A. \& HigneTt, R. C. (1976). Properties of phage receptor lipopolysaccharide from Pseudomonas morsprunorum. Journal of General Microbiology 96, 375-381.

RIETSCHEL, E., GOTTERT, H., LÜDERITZ, O. \& WESTPHAL, O. (1972). Nature and linkages of the fatty acids present in the lipid A component of Salmonella lipopolysaccharides. European Journal of Biochemistry 28, 166-173.

Rondle, C. J. M. \& Morgan, W. T. J. (1955). Determination of glucosamine and galactosamine. Biochemical Journal 61, 586-589.

Rowe, P. S. N. \& Meadow, P. M. (1983). Structure of the core oligosaccharide from the lipopolysaccharide of Pseudomonas aeruginosa PAC1R and its defective mutants. European Journal of Biochemistry 132, 329337.

SAINI, A. S. (1966). Technical improvements in paper chromatography of sugars: method of sample desalting and sensitive staining reagent. Journal of Chromatography 24, 484-486.

Salkinoja-Salonen, M. \& BoECK, R. (1978). Characterization of lipopolysaccharides isolated from Agrobacterium tumefaciens. Journal of General Microbiology 105, 119-125.

Smith, A. R. W. \& HignetT, R. C. (1981). Composition of lipopolysaccharide from Pseudomonas morsprunorum and its digestion by bacteriophage A7. Society for General Microbiology Quarterly 8, 262.

TsaI, C.-M. \& Frasch, C. E. (1982). A sensitive silver stain for detecting lipopolysaccharides in polyacrylamide gels. Analytical Biochemistry 119, 115-119.

WeISSBACH, A. \& HuRWITZ, J. (1959). The formation of 2-keto-3-deoxyheptonic acid in extracts of Escherichia coli B. Journal of Biological Chemistry 234, 705709.

WestPhal, O. \& JANN, K. (1965). Bacterial lipopolysaccharides: extraction with phenol-water and further applications of the procedure. Methods in Carbohydrate Chemistry 5, 83-91.

Wilkinson, S. G. \& Galbraith, L. (1975). Studies of lipopolysaccharides from Pseudomonas aeruginosa. European Journal of Biochemistry 52, 331-343.

Wilkinson, S. G., Galbraith, L. \& Lightfoot, G. A. (1973). Cell walls, lipids and lipopolysaccharides of Pseudomonas spp. European Journal of Biochemistry 33, $158-174$.

Wright, A., McConnell, M. \& Kanegasaki, S. (1980). Lipopolysaccharide as a bacteriophage receptor. In Receptors and Recognition series B, vol. 7, part 1, pp. 29-57. Edited by L. L. Randell \& L. Philipson. London: Chapman \& Hall. 